Article

\title{
Functional Properties of Banana Starch (Musa spp.) and Its Utilization in Cosmetics
}

\author{
Norramon Thanyapanich ${ }^{1}$, Ampa Jimtaisong ${ }^{1,2, *(\mathbb{D})}$ and Saroat Rawdkuen ${ }^{2,3}$ (D) \\ 1 School of Cosmetic Science, Mae Fah Luang University, 333, Moo.1, Thasud, Muang, \\ Chiang Rai 57100, Thailand; n.nanorr@gmail.com \\ 2 Unit of Innovative Food Packaging \& Biomaterials (IFP), Mae Fah Luang University, 333, Moo.1, Thasud, \\ Muang, Chiang Rai 57100, Thailand; saroat@mfu.ac.th \\ 3 School of Agro-Industry, Mae Fah Luang University, 333, Moo.1, Thasud, Muang, Chiang Rai 57100, Thailand \\ * Correspondence: ampa@mfu.ac.th; Tel.: +6653-916-843
}

Citation: Thanyapanich, N.; Jimtaisong, A.; Rawdkuen, $\mathrm{S}$ Functional Properties of Banana Starch (Musa spp.) and Its Utilization in Cosmetics. Molecules 2021, 26, 3637 https://doi.org/10.3390/

molecules 26123637

Academic Editor: Michel Baltas

Received: 12 May 2021

Accepted: 8 June 2021

Published: 14 June 2021

Publisher's Note: MDPI stays neutral with regard to jurisdictional claims in published maps and institutional affiliations.

Copyright: (c) 2021 by the authors. Licensee MDPI, Basel, Switzerland This article is an open access article distributed under the terms and conditions of the Creative Commons Attribution (CC BY) license (https:// creativecommons.org/licenses/by/ $4.0 /)$.
Abstract: Unripe banana fruit of Musa acuminata (Musa AAA; Hom Khieo) and Musa sapientum L. (Musa ABB; Namwa) growing in Chiang Rai (Thailand) were used for extraction. The yield of the starches was $16.88 \%$ for Hom Khieo (HK) and $22.73 \%$ for Namwa (NW) based on unripe peeled banana fruit. The amylose contents of HK and NW were $24.99 \%$ and $26.23 \%$, respectively. The morphology of starch granules was oval shape with elongated forms for large granules and round shape for small granules. The HK and NW showed B-type crystalline structure and the crystallinities were $23.54 \%$ and $26.83 \%$, respectively. The peak temperature of gelatinization was around $77^{\circ} \mathrm{C}$ and the enthalpy change $(\Delta \mathrm{H})$ was 3.05 and $7.76 \mathrm{~J} / \mathrm{g}$, respectively. The HK and NW banana starches showed $1.27 \pm 0.12 \mathrm{~g} / \mathrm{g}$ and $1.53 \pm 0.12 \mathrm{~g} / \mathrm{g}$ water absorption capacity, and $1.22 \pm 0.11 \mathrm{~g} / \mathrm{g}$ and $1.16 \pm 0.12 \mathrm{~g} / \mathrm{g}$ oil absorption capacity, respectively. The swelling power of the banana starches was $17.23 \pm 0.94 \mathrm{~g} / \mathrm{g}$ and $15.90 \pm 0.15 \mathrm{~g} / \mathrm{g}$, respectively, and the percentage of solubility in water showed $26.43 \pm 2.50 \mathrm{~g} / \mathrm{g}$ and $20.54 \pm 0.94 \mathrm{~g} / \mathrm{g}$, respectively. The banana starches showed very poor flow character. The HK and NW starches have the potential to be used in powder base preparations with no effect on the sensory texture of the product at $15 \% w / w$ maximum.

Keywords: amylose content; banana starch; characterization; functional properties; Musa spp.

\section{Introduction}

Starch is a natural polysaccharide which is a semi-crystalline structure consisting of amylose and amylopectin. Amylose is a straight chain, whereas amylopectin has a branched chain structure. Starch can be extracted from various plant sources, especially tropical plants such as cereals, tubers, and some unripe fruits which have polysaccharide contents are in the range of $60-90 \%[1,2]$. Bananas are edible fruit cultivars with dietary characteristics that are an important source to people [3]. The banana is a tropical fruit that belongs to the Musaceae botanical family. The Musaceae are monocotyledon herbaceous plants that represent hybrid-polyploid complexes of Musa acuminata (AA) and Musa balbisiana (BB), as diploids, triploids, and tetraploids [4]. Generally, bananas with a high proportion of $M$. balbisiana (B genes) tend to be more tolerate and produce more starch than bananas with high proportion of M. acuminata (A genes) [5]. The main component of green bananas is starch with about $70-80 \%$, based on dry weight, but this changes dramatically during ripening from starch to sugar [6].

In Thailand, bananas are called "Kluai" and the varieties that widely cultivated in Thailand are Kluai Namwa (ABB group), Kluai Hom (AAA group), Kluai Khai (AA group) and Kluai Lep Meu Nang (AA group) [7]. Most bananas in Thailand are grown as an economic product for consumption and exportation, with an estimated amount of 27,452 tons of bananas exported in 2011-2019. Damaged or too-small bananas will be culled and become waste. There is an attempt to bring the culled bananas to be used as 
animal feeds, but these products have low value. The production of starch from the banana culls can improve banana economics and eliminate environmental problems [8]. Natural starch plays an important role in various industries such as the food, pharmaceutical, and cosmetic industries. It can be used both as powdered starch and gelatinized starch. Generally, starch provides smoothness when rubbed on the skin and can improve the smoothness of products $[9,10]$. Starch also act as a thickening agent, gelling agent, and stabilizing agent. The thickening agent from starch is effective in stabilizing emulsions to avoid phase separation [11-13]. Starch is also used in powder formulation, according to Rincón et al. [14], guapo starch has been used in the preparation of face powders as a substitute for talcum, and a satisfaction rating was assessed against a base formulation. Sago starch has also been used in body powder formulations. Satisfaction assessments of perfumed and cooling body powders containing sago starch were similar to the commercial formulation [15]. Thus, it is interesting to find an alternative source of natural starch as a substitute for talcum and use as an ingredient in cosmetic preparation.

Recently, we have preliminarily reported the basic properties such as morphology, amylose content, crystalline structure and the thermal properties of M. acuminata (AAA group) [16]. In this study, the banana starch from Namwa (NW), a member of sapientum subgroup in the ABB group, was investigated alongside, and compared to, the HK starch in terms of yield and properties. Additionally, the utilization of starch as an ingredient in cosmetic formulation was also described.

\section{Results and Discussion}

\subsection{Extraction of Banana Starch}

The percentage yield of HK and NW that was obtained from extraction with $1 \%$ sodium sulfite was 16.88 and $22.73 \%$, respectively, calculated based on fresh peeled banana. It can be seen that NW (Musa ABB) had higher yield than HK (Musa AAA), as it has been reported that bananas with high proportion of $B$ genes tend to produce more starch than that with high proportion of A genes [4]. However, the yields of HK and NW starches were in the normal range compared with those found in previous studies. According to Bello-Perez et al. [17], the yields of M. paradisiaca (AAB) and M. acuminata (AAA) were $43.8 \%$ and $11.8 \%$, respectively. Chávez-Salazar et al. [18] reported that the yield of $M$. paradisiaca (AAB), and $M$. acuminata (AAA) were $32.33 \%$ and $18.73 \%$, respectively. The variety and texture of fruit affect the yield of starch, lower firmness results in lower yield than higher firmness, which is related to the stage of ripeness $[8,17]$.

The starches showed light yellow color (Figure 1) with fine texture and light characteristic banana odor. The color values that obtained from the colorimeter in term of $\mathrm{L}^{*}, \mathrm{a}^{*}$, and $b^{*}$ are $82.67,2.83$, and 10.92, and 89.57, 1.61, and 9.03 for HK and NW, respectively. The color values of $\mathrm{HK}$ banana starch obtained were similar to those reported by Falade \& Oyeyinka [19] as L*, a*, and b* of Agbagba (Musa AAB), Cooking bananas (Musa ABB), and Obino I'Ewai (Musa AAB) were in range of 81.30-82.03, 1.82-2.18, and 11.11-12.19, respectively. Whereas, NW was slightly lighter, less green, and less yellow.

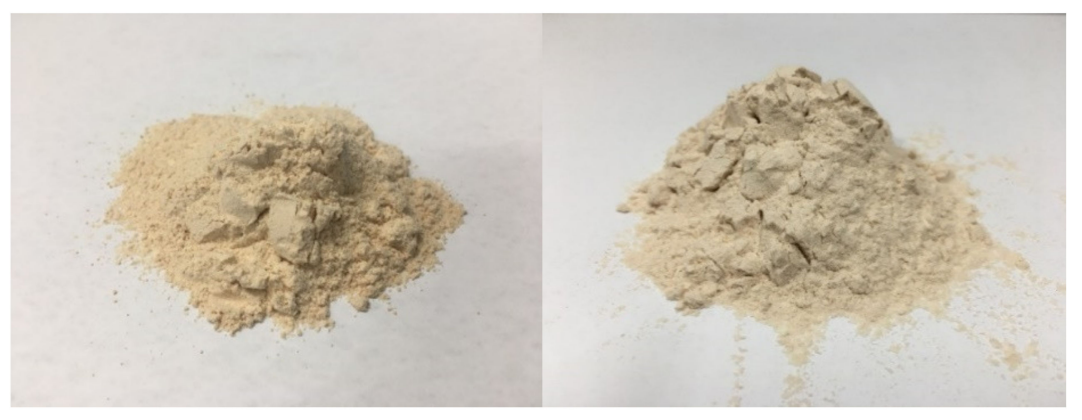

(a)

(b)

Figure 1. Appearance of banana starch (a) M. acuminata (AAA; HK) (b) M. sapientum L. (ABB; NW). 


\subsection{Amylose Content}

Starch is a polysaccharide, consisting of amylose and amylopectin. In general, common starch constitutes of 20-30\% amylose and 70-80\% amylopectin [20,21]. Amylose contents of starch granules extracted from HK and NW were $24.99 \pm 1.03 \%$ and $26.23 \pm 0.27 \%$, respectively. The amylose contents of $\mathrm{HK}$ and NW were similar to those found in a previous study by Barros Mesquita et al. [22], in which amylose content of Musa AAA (25.31-26.54\%) was slightly lower than Musa AAB (26.42-29.01\%). The results reported in the study of Utrilla-Coello et al. [23] showed that the amylose content of Musa AAA (19.32-21.99\%) was lower than Musa AAB (26.35\%) and Musa ABB (25.38\%). The amylose content plays an important role in influencing diverse physicochemical and functional properties of starches. The differences of amylose content depend on the variety, growth condition and the state of maturity of the plant $[18,21,22]$.

\subsection{Moisture Content}

The percentage of moisture content of $\mathrm{HK}$ and NW were $13.10 \pm 0.10 \%$ and $13.40 \pm 0.40 \%$, respectively. The moisture content was similoar to that found by Barros Mesquita et al. [22] which reported the moisture content of Musa AAA and Musa AAB in a range of 8.60-14.00\%. The moisture content affected the properties of starch as higher moisture content has the ability to bind with water but low ability to flow $[24,25]$.

\subsection{Morphology}

The HK and NW starch granules exhibited various sizes and shapes. The large size of both HK and NW starches was an oval shape with elongated form. The average size of HK was around $39 \mu \mathrm{m}$, which was close to that of NW $(37 \mu \mathrm{m})$, while the smaller size of HK and NW was round shape with a size around $10 \mu \mathrm{m}$. The HK and NW granules had a higher proportion of large sizes than smaller sizes. The appearance of granules from the SEM showed that their surfaces were smooth and dense (Figure 2).

The banana starch granules were similar to the previous studies of various cultivars which were irregular elongated oval shape with dense and smooth surfaces [23,26-29]. However, both the size and shape of the banana starch granules depends on the banana cultivar. Some cultivars were rod, or round with clefts shaped [30]. The size of the HK and NW starch granules in this study is in the range of that found by Bello-Pérez et al. [26] ranging between $35-55 \mu \mathrm{m}$, while the small size was around 7-8 $\mu \mathrm{m}$.

The morphology of starch depends on the botanical source that affects the shapes and size of starch granules. Starch granules of corn are angular-shaped with 1-7 $\mu \mathrm{m}$ for small granules and 15-20 $\mu \mathrm{m}$ for large granules. Rice starch granules are pentagonal with angular-shapes and the granules sizes range from 3 to $5 \mu \mathrm{m}$. Whereas potato starch granules are oval and irregular shapes with 1-20 $\mu \mathrm{m}$ for the granule size. The SEM images of potato starch granules are smoother than those of corn and rice starch granules [31]. In this work, the banana starch granules showed smoother surfaces than corn and rice starch, similar to the potato starch granules that give the smooth feeling. HK and NW starch granules were larger than corn, rice, and potato starch. However, the variety of granule size and shape depends on the starch source that affected the physicochemical and functional properties of the starch [30,31]. 


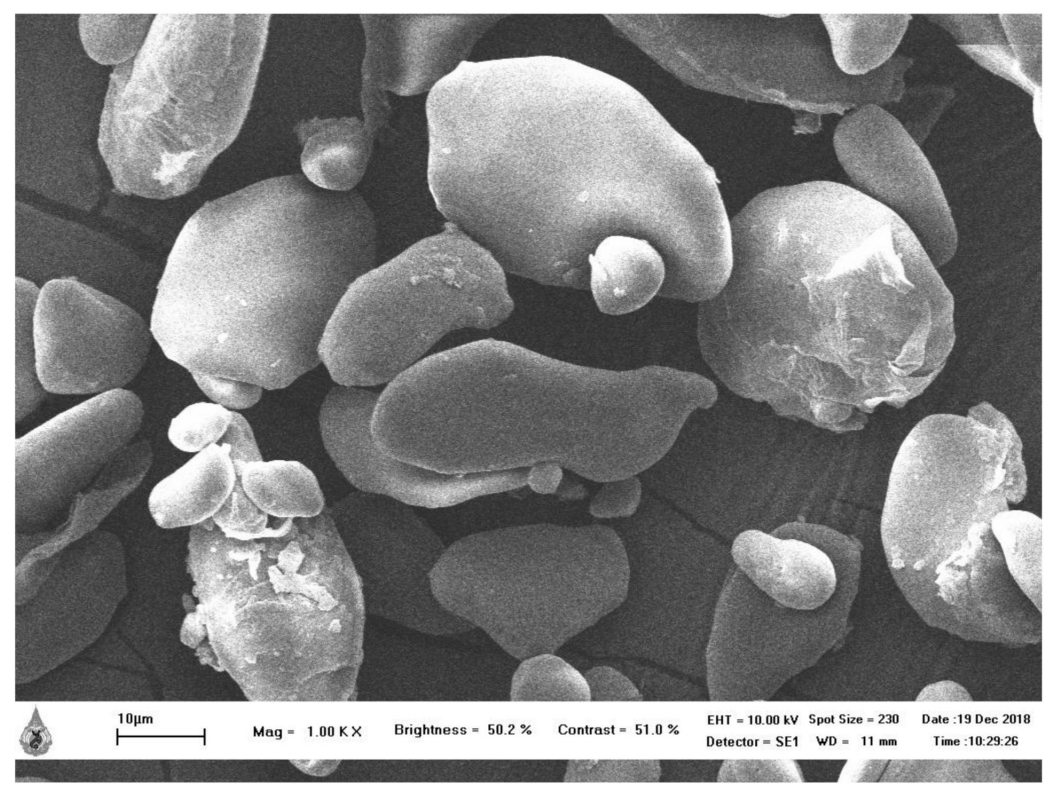

(a)

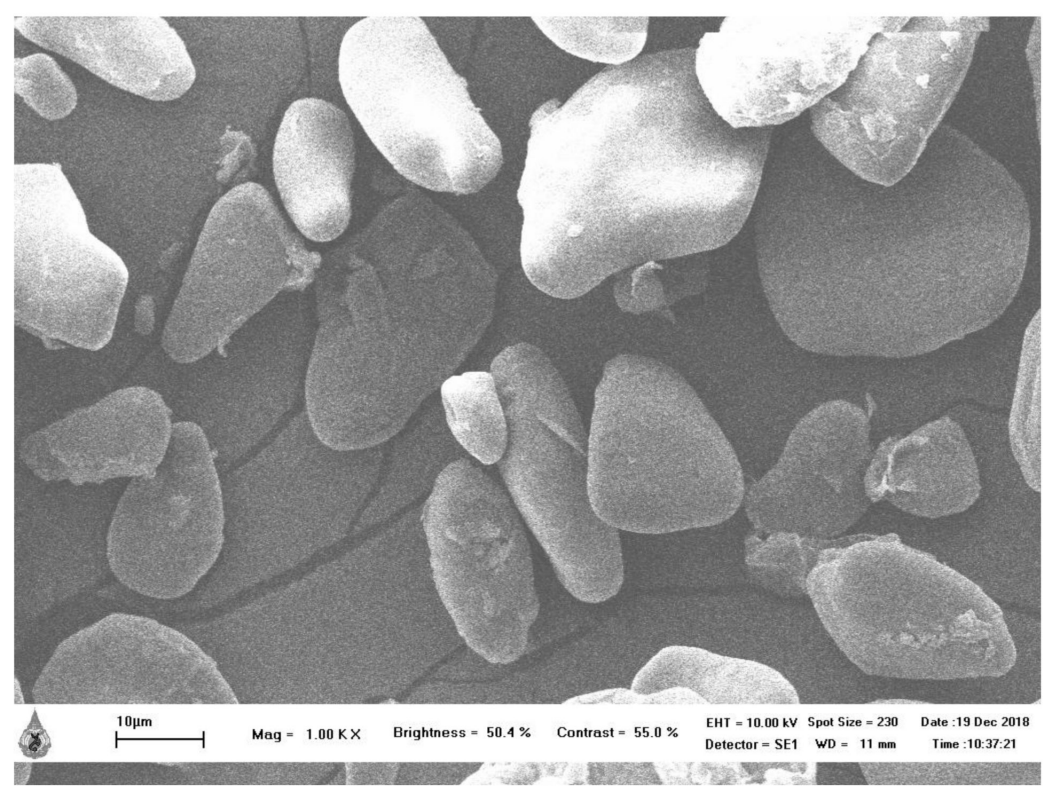

(b)

Figure 2. The morphology of banana starch at $1000 \times$ (a) M. acuminata (AAA; HK) (b) M. sapientum L. $(\mathrm{ABB} ; \mathrm{NW})$.

\subsection{FT-IR Spectroscopy}

The FT-IR spectra of HK and NW starch samples are shown in Figure 3. The spectra showed peaks at around $3300 \mathrm{~cm}^{-1}$ (O-H stretching); $2900 \mathrm{~cm}^{-1}$ (C-H stretching); $1650 \mathrm{~cm}^{-1}$ (C-O associated with $\mathrm{OH}$ group); $1424 \mathrm{~cm}^{-1}\left(\mathrm{CH}_{2}\right.$ symmetric deformation); $1370 \mathrm{~cm}^{-1}$ (C-H symmetric bending); $1160 \mathrm{~cm}^{-1}$ (C-O-C asymmetric stretching); $1082 \mathrm{~cm}^{-1}$ and $1000 \mathrm{~cm}^{-1}$ (C-O stretching); and $930 \mathrm{~cm}^{-1}, 860 \mathrm{~cm}^{-1}$, and $767 \mathrm{~cm}^{-1}$ (C-O-C ring vibration of carbohydrate). The FT-IR spectra obtained from this study were similar to those from a previous report [20]. 


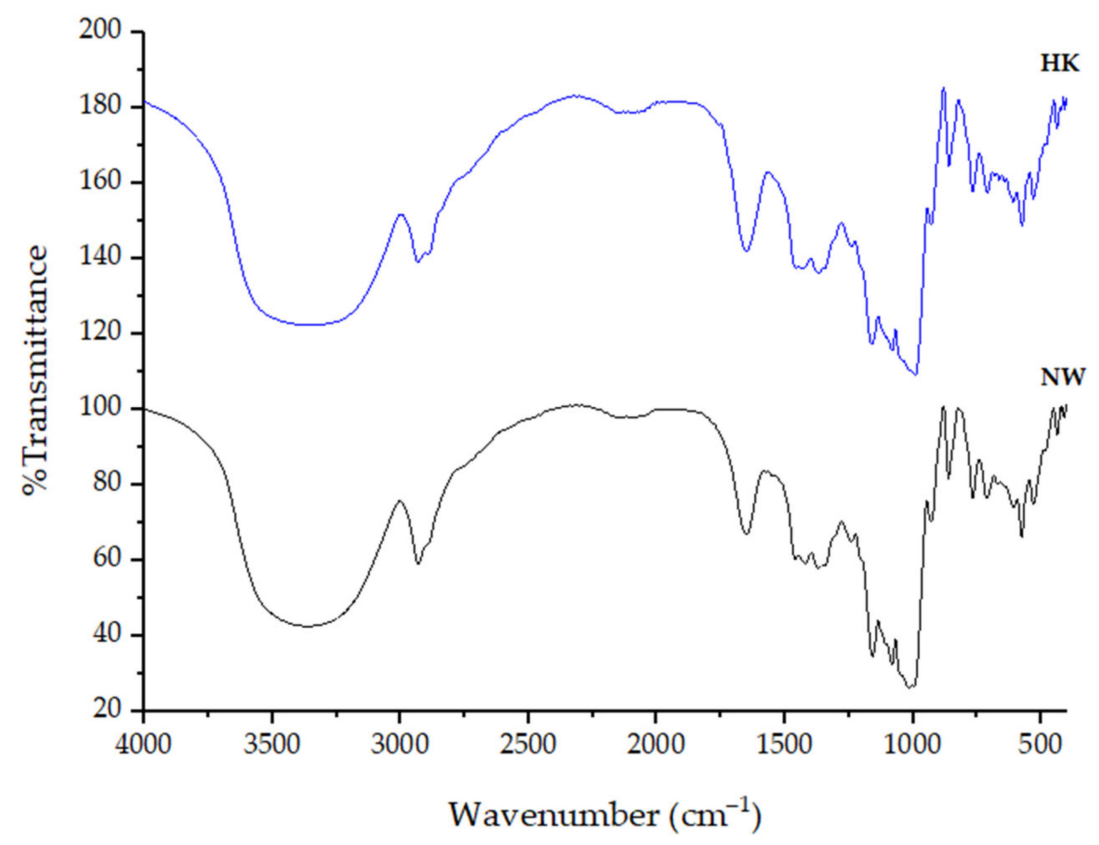

Figure 3. FT-IR of M. acuminata (AAA; HK) and M. sapientum L. (ABB; NW) starches.

\subsection{X-Ray Diffractometer (XRD)}

Starch is a semi-crystalline material affected by amylose content and amylopectin chain length that consists of amorphous and crystalline regions. The crystalline region is parallel of glucan chains (amylopectin) that are closely packed and ordered, whereas the amorphous region is the linear region (amylose). The amylose content directly affects the crystallinity degree of the starch, such that when there is a lack of amylose content, the crystallinity degree increases, whereas the longer chain amylopectin forms have a more stable crystalline structure [32,33]. Generally, the starch crystalline structure was divided into three types, which are A-type, B-type, and C-type that depended on the variety of starch source. The crystalline structure was determined by using the XRD technique. A-type starch showed strong peaks at a $2 \theta$ of about $15^{\circ}$, and $23^{\circ}$ and small peaks at about $17^{\circ}$ and $18^{\circ}$. However, the strong peaks of B-type presented at about $17^{\circ}$ and small peaks at about $15^{\circ}, 20^{\circ}, 22^{\circ}$, and $24^{\circ}$ with a characteristic peak at about $5^{\circ}$. The peaks of C-type starch were a mixture of A-type and B-type at $2 \theta s$ of about $17^{\circ}$ and $23^{\circ}$ and small peaks at $5^{\circ}$ and $15^{\circ}[34-36]$.

The X-ray diffraction pattern of HK was similar to that of NW starches (Figure 4). The HK showed a pattern with major peaks at $2 \theta$ s of about $15.12^{\circ}, 17.07^{\circ}$ and a doublet at $22.13^{\circ}$ and $23.64^{\circ}$, with weak diffraction peaks at $5.31^{\circ}$ and $19.83^{\circ}$, with $23.54 \%$ crystallinity. The NW was identified by major diffraction peaks at $2 \theta s$ of $15.30^{\circ}, 17.22^{\circ}$, and a doublet at $22.70^{\circ}$ and $23.90^{\circ}$ with weak diffraction peaks at $5.76^{\circ}$ and $19.81^{\circ}$, with $26.84 \%$ crystallinity. From the X-ray pattern of the HK and NW starch granules, they were determined to be B-type starches.

The major difference between A- and B-types of starch granules is the arrangement of double helices. A-type starches form dense packing with 4 water molecules, whereas B-type starch is more open causing more water molecules (36 water molecules) to be located in the center of a hexagonal packing of helices. For this reason, it is indicated that the A-type is more stable and requires a higher temperature than B-type starch for gelatinization $[11,34,37]$. 


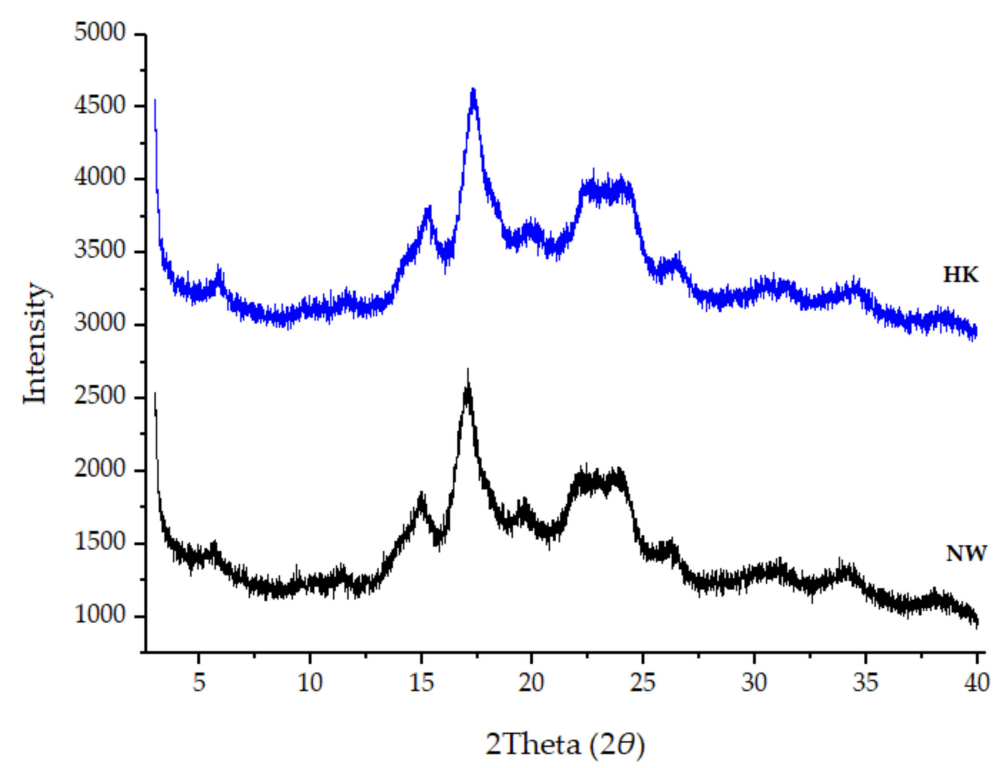

Figure 4. X-ray diffraction pattern of HK and NW starch granules.

\subsection{Thermal Properties}

The differential scanning calorimetry (DSC) and gelation methods were used to determine the thermal properties of banana starches. The thermal properties from DSC were measured in terms of transition temperature; onset (To), the starting point of starch gelatinization; peak (Tp), the point where a complete loss of crystalline occurs; and end set (Te), the final temperature required to complete the gelatinization. The enthalpy $(\Delta \mathrm{H})$ is consistent with the changes of energy during melting of the crystallites and measures the crystallinity or damage in the starch structure before gelatinization occurs [38-40].

The HK banana starch has an onset gelatinization temperature (To) of $74.52{ }^{\circ} \mathrm{C}$, a peak gelatinization temperature $(\mathrm{Tp})$ of $77.97^{\circ} \mathrm{C}$, and an endpoint gelatinization temperature (Te) of $80.37{ }^{\circ} \mathrm{C}$, with gelatinization enthalpy $(\Delta \mathrm{H})$ of $3.05 \mathrm{~J} / \mathrm{g}$. The $\mathrm{NW}$ banana starch has an onset gelatinization temperature (To) of $73.64{ }^{\circ} \mathrm{C}$, a peak gelatinization temperature (Tp) of $76.98{ }^{\circ} \mathrm{C}$, and an endpoint gelatinization temperature (Te) of $80.69{ }^{\circ} \mathrm{C}$, with gelatinization enthalpy $(\Delta \mathrm{H})$ of $7.76 \mathrm{~J} / \mathrm{g}$ (Table 1$)$. The results were in agreement with a previous study that found the gelatinization temperatures of banana starches are in a range of $70-79^{\circ} \mathrm{C}$. The enthalpy $(\Delta \mathrm{H})$ of $\mathrm{NW}$ was higher than that of $\mathrm{HK}$, indicating that $\mathrm{NW}$ had a higher proportion of crystalline structure than HK starch, which is related to the results of crystallinity $[1,18,23,26,41-43]$.

Table 1. Thermal properties of HK and NW banana starch obtained using DSC technique.

\begin{tabular}{ccccc}
\hline Starch & To $\left({ }^{\circ} \mathbf{C}\right)$ & $\mathbf{T p}\left({ }^{\circ} \mathbf{C}\right)$ & Te $\left({ }^{\circ} \mathbf{C}\right)$ & $\Delta \mathbf{H}(\mathbf{J} / \mathbf{g})$ \\
\hline HK & $74.52 \pm 0.17$ & $77.97 \pm 0.21$ & $80.37 \pm 0.50$ & $3.05 \pm 0.83$ \\
NW & $73.64 \pm 0.32$ & $76.98 \pm 0.21$ & $80.69 \pm 0.23$ & $7.76 \pm 0.74$ \\
\hline
\end{tabular}

According to Mar et al. [44] the high degree of crystallinity is the cause of the high transition temperature values of starches, which provides structural stability and makes the starch granules more resistant to gelatinization. The higher percentage crystallinity of amylopectin requires the higher gelatinization enthalpy $(\Delta \mathrm{H})[45,46]$. For the gelation method, the starch concentration was varied $(0.5,1,2,4,6,8,10,12$, and 14\% w/v) at different temperatures $\left(55,65,75\right.$, and $\left.80^{\circ} \mathrm{C}\right)$ and it was found that all samples at temperatures lower than $80{ }^{\circ} \mathrm{C}$ with low concentrations $(0.5-6 \% w / v)$ did not show gel formation and high concentrations $(8-14 \% w / v)$, showed some of gel forming. At $80{ }^{\circ} \mathrm{C}$, the gelation of HK and NW starches are shown in Figures 5 and 6, they presented that the 
concentrations of 0.5 to $6 \% w / v$ showed some gel forming. At $8 \% w / v$ the starch presented the gel formation stage. The banana starch showed complete gel formation at 10 to $14 \%$ $w / v$. The results indicated that the gelatinization temperatures of $\mathrm{HK}$ and NW obtained from the DSC method were related to those found by the gelation method.

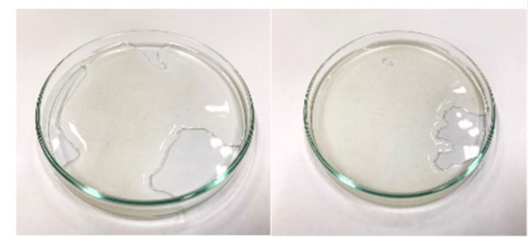

(a) 0.5

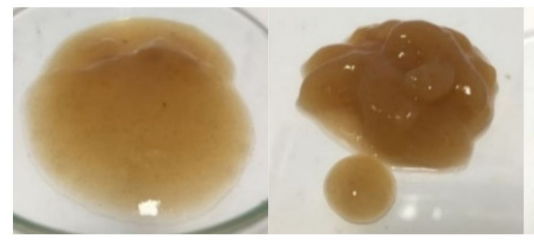

(e) 6 (b) 1

(f) 8

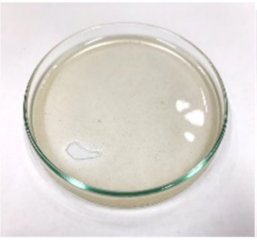

(c) 2

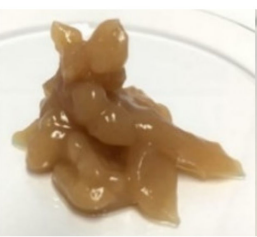

(g) 10

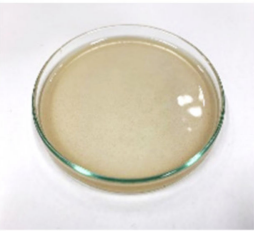

(d) 4

Figure 5. Gelation of $\mathrm{HK}$ banana starch at $80{ }^{\circ} \mathrm{C}$ at different concentrations where (a) $0.5 \% w / v$, (b) $1 \% w / v$, (c) $2 \% w / v$, (d) $4 \% w / v$, (e) $6 \% w / v,(\mathbf{f}) 8 \% w / v$, (g) $10 \% w / v,(\mathbf{h}) 12 \% w / v$, and (i) $14 \% w / v$.

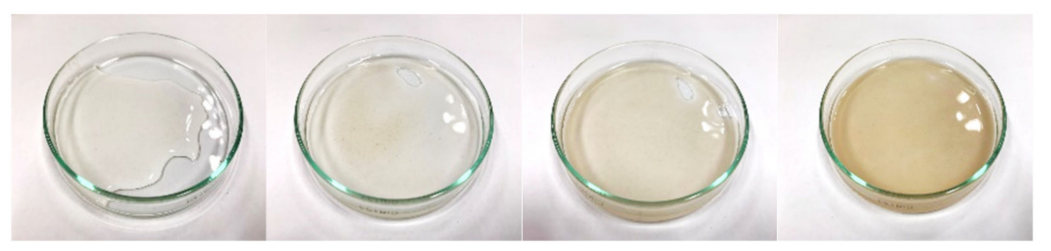

(a) 0.5

(b) 1

(c) 2

(d) 4

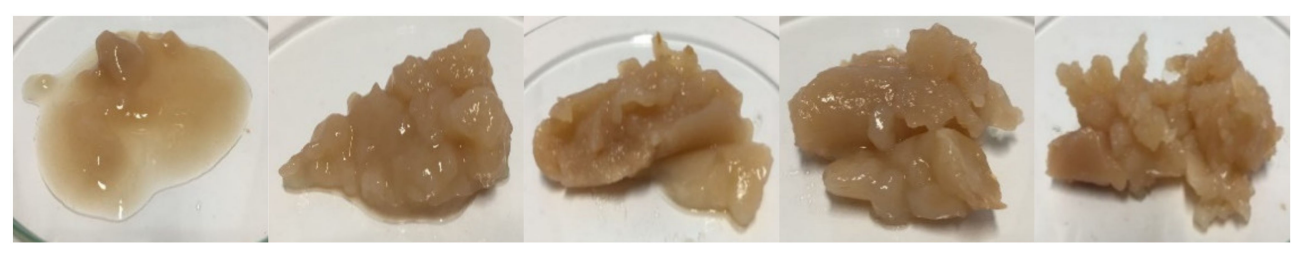

(e) 6

(f) 8

(g) 10

(h) 12

(i) 14

Figure 6. Gelation of NW banana starch at $80{ }^{\circ} \mathrm{C}$ at different concentrations where (a) $0.5 \% w / v$, (b) $1 \% w / v$, (c) $2 \% w / v$, (d) $4 \% w / v,(\mathbf{e}) 6 \% w / v,(\mathbf{f}) 8 \% w / v,($ g) $10 \% w / v,(\mathbf{h}) 12 \% w / v$, and (i) $14 \% w / v$.

\subsection{Water and Oil Absorption Capacities}

The water absorption capacities (WAC) of HK and NW were $1.27 \pm 0.12 \mathrm{~g} / \mathrm{g}$ and $1.53 \pm 0.12 \mathrm{~g} / \mathrm{g}$ whereas the oil absorption capacities (OAC) of HK and NW were $1.22 \pm 0.11 \mathrm{~g} / \mathrm{g}$ and $1.16 \pm 0.12 \mathrm{~g} / \mathrm{g}$, respectively. The WAC represents the ability of a substance to associate with water under a limited water condition. Agnes et al. [47] reported that water absorption capability is useful to indicate that starch granules can be associated with aqueous formulations. 


\subsection{Swelling Power and Solubility}

The swelling power and solubility of HK and NW were directly related to increases in temperature. Both HK and NW starches showed a two-stage process. The initial stage was in range of $60-70^{\circ} \mathrm{C}$ where the starches exhibited low swelling, then a significant increase showed above $70^{\circ} \mathrm{C}$, which is in agreement with previous studies [48-50]. At temperatures above $70{ }^{\circ} \mathrm{C}$, both $\mathrm{HK}$ and NW swelled rapidly until $90{ }^{\circ} \mathrm{C}(17.23 \pm 0.94 \mathrm{~g} / \mathrm{g}$ and $15.90 \pm 0.15 \mathrm{~g} / \mathrm{g}$ ) that showed the highest swelling power (Figure 7a). During the initial stage, the starches exhibited slight swelling due to hydrogen bonds in the starch granules forming a complex of lipids and proteins that restricted swelling. At above $70{ }^{\circ} \mathrm{C}$, the hydrogen bonds were disrupted and allowed water penetrated into the starch granules that increased swelling [51].

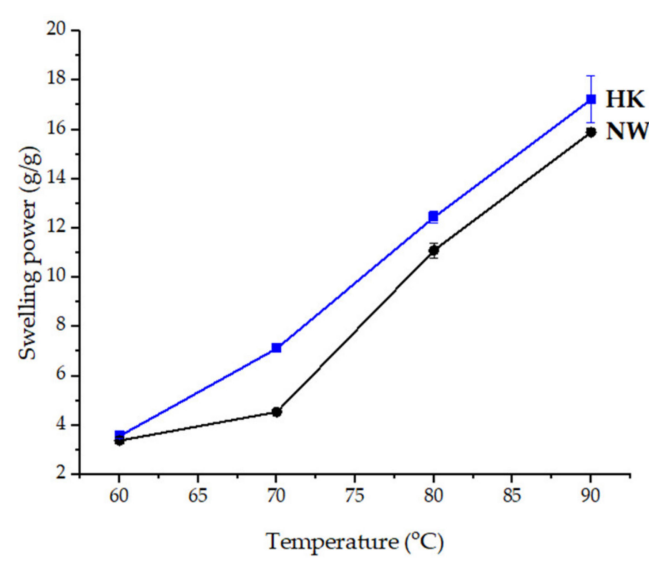

(a)

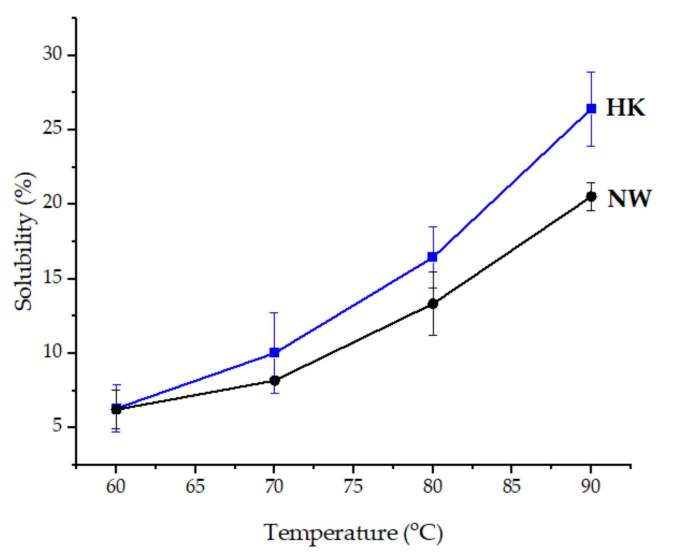

(b)

Figure 7. (a) swelling power of HK and NW banana starches (b) solubility of HK and NW banana starches.

Amylose content maybe one of the factors affecting the swelling power of $\mathrm{HK}$ and NW starches due to the lower amylose content of HK causing the higher swelling power than the NW starch. HK and NW banana starch solubility also increased with temperature, reaching $26.43 \pm 2.50 \%$ and $20.54 \pm 0.94 \%$ at $90{ }^{\circ} \mathrm{C}$, respectively (Figure $7 \mathrm{~b}$ ). The $\mathrm{HK}$ starch has slightly higher solubility than NW due to the lower amylose content, which is in agreement with Rodríguez-Torres et al. [52].

The starch granule is a water-insoluble compound that can be hydrated at high temperatures. The disorder of starch crystallinity from heating can hydrate and swell the starch granules [39]. The swelling power is dependent on the granule structure that is obtained from different starch source. The broken of $\mathrm{H}$-bonds from heating allowed the swelling of the granules. The swelling power depends on the water holdeing capacity via amylose content, chains of amylopectin, and H-bonds [18,53]. The high amylopectin content causes high swelling power and high viscosity at low temperature [54]. The pores on the starch surface allow water to penetrate and interrupt the amylose in amorphous regions and improves the swelling power of starch granules [55]. The size of the starch granules also effects the swelling power as the smaller size causes higher swelling power. The small size starch granules have a high amylopectin content which is highly crystalline and allows more swelling power [18,38]. Amylose content affected the swelling power and solubility in an inverse relationship. The high swelling power was due to the low amylose content, which is in accordance with the results of Mtunguja et al. [56], who reported that the higher amylose content causes low swelling power of cassava starches and agreed with Sánchez et al. [57] that the waxy cassava starches had the highest swelling power. 


\subsection{Flow Properties}

The flow character of HK and NW banana starches was obtained from examination and compared with the compressibility index (CI) and Hausner ratio (HR) chart (Table 2). The HK and NW banana starches showed very poor flow properties with $31.70 \pm 2.13$ and $34.84 \pm 1.59$ compressibility indeces, and $1.47 \pm 0.05$ and $1.54 \pm 0.04$ Hausner ratios, respectively. Generally, the moisture content and water absorption capacity affect the flowability of starches and are always inversely correlated. The higher moisture content and water absorption capacity causes more water absorption which results in increased cohesion and decreased flowability [24,58-61]. The particle size of starches also influences the flowability in that fine or small sized granules flowed less freely than large sized granules and the presence of a high proportion of fine granules reduces the flowability. The very poor flowability of the NW starch showed higher values in the compressibility ratio and Hausner ratio that are related to its higher water absorption capacity than the HK starch.

Table 2. The relationship between Compressibility index, Hausner ratio, and flowability.

\begin{tabular}{ccc}
\hline Flow Character & HR & CI (\%) \\
\hline Excellent/very free flow & $1.00-1.11$ & 10 \\
Good/free flow & $1.12-1.18$ & $11-15$ \\
Fair & $1.19-1.25$ & $16-20$ \\
Passable & $1.26-1.34$ & $21-25$ \\
Poor/cohesive & $1.35-1.45$ & $26-31$ \\
Very poor/very cohesive & $1.46-1.59$ & $32-37$ \\
Very very poor/approx. non-flow & $>1.60$ & $>38$ \\
\hline
\end{tabular}

\subsection{Cosmetic Formulation}

Currently, the trend of using natural materials in the cosmetic industry is on the rise. Consumers demand natural ingredients to replace synthetic ingredients because synthetic ingredients can have possible negative effects on health. For this reason, to satisfy the consumer, industry needs to develop cosmetics based on natural ingredients $[62,63]$. According to previous research, it has been found that asbestos can be found in powders containing talcum powder, which negatively affects the respiratory system and contributes to ovarian cancer. At present, powder formulations have been developed to have a lower amount of talcum by replacing it with natural starch [64-66]. The powder base preparation was chosen due to the smooth surface of starch granules and the smoothness when applied on skin, a preliminary study was conducted on body powder and compact powder.

Body powder and compact powder containing HK or NW in a range of 5 to $20 \%$ were prepared. It was found that the products with a starch component in the range of 5 to $15 \%$ provided a smooth and soft touch similar to that of the base formulations whereas at higher than $15 \%$, it has a less smooth and soft touch. The $15 \%$ HK and NW body powder showed a light-yellow color (Figure 8) with light banana odor. For 15\% HK and NW compact powder, they showed a beige color (Figure 9) due to other colorants in the formula, with a light banana odor. It was found that when HK or NW starch was added into the formulation, it provided smoothness and could be used as a substitute for talcum powder. A sensory test in volunteers should be studied further. In addition, the flow properties of a body powder containing $15 \% \mathrm{HK}$ and NW were similar to the base formulation (Table 3). From these results, the HK and NW starch has the potential to be used as a substitute for talcum in powder base preparation. However, the HK and NW starches needs to be modified to reduce their water absorption, which may improve the smoothness of product when use in higher quantities in powder formulation. 


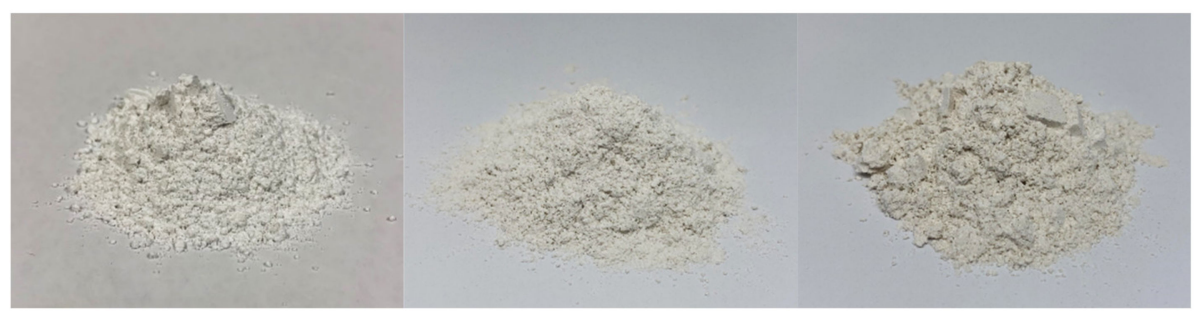

(a)

(b)

(c)

Figure 8. Appearance of body powder (a) base body powder (b) containing M. acuminata (AAA) (c) containing M. sapientum L. (ABB).

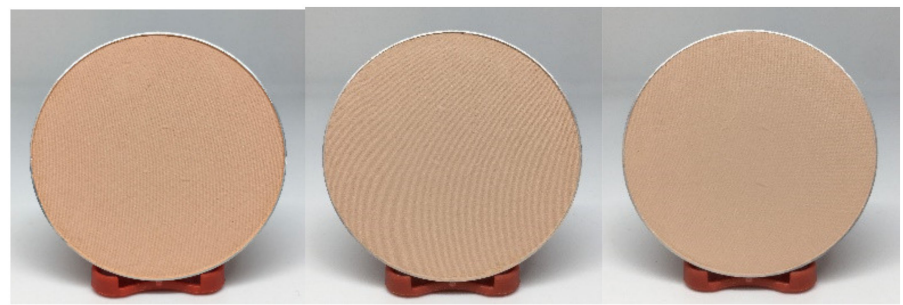

(a)

(b)

(c)

Figure 9. Appearance of compact powder (a) base compact powder (b) containing M. acuminata (AAA) (c) containing M. sapientum L. (ABB).

Table 3. The flow properties of the body powder containing $15 \%$ starch.

\begin{tabular}{cccc}
\hline & Base Body Powder & HK Body Powder & NW Body Powder \\
\hline Density & $0.88 \pm 0.02$ & $0.84 \pm 0.03$ & $0.86 \pm 0.01$ \\
Hausner ratio & $1.84 \pm 0.05$ & $1.78 \pm 0.06$ & $1.86 \pm 0.03$ \\
Compressibility index & $45.85 \pm 1.50$ & $43.67 \pm 1.95$ & $45.62 \pm 0.59$ \\
\hline
\end{tabular}

\section{Materials and Methods}

\subsection{Extraction of Banana Starch}

The extraction method for the banana starches was a slight modification of the method used by Bello-Pérez et al. [17]. Two varieties of unripe banana which are Hom Khieo (M. acuminata; AAA) and Namwa (M. sapientum; ABB) banana cultivars were used. The unripe bananas were peeled and cut into small cube pieces then placed into a blender and $1 \% w / v$ of sodium sulfite solution was added to immerse the banana in a ratio of $1: 2 w / v$. The samples were blended in the blender at maximum speed for $10 \mathrm{~min}$ then filtered with 200 mesh sieving and white cloth to remove the pulp. After being sieved, the samples were centrifuged at $8500 \mathrm{rpm}$ for $5 \mathrm{~min}$ to precipitate the starch. The precipitated starches were dried at $40{ }^{\circ} \mathrm{C}$ in a hot air oven overnight. The dried banana starches were ground by using mortar and pestle then sieved with a $125 \mu \mathrm{m}$ mesh. The percentage of yield of banana starch was calculated as

$$
\text { The percentage of yield }=\frac{\text { Weight of dry starch }}{\text { Initial weight of fresh peeled unripe banana fruit }} \times 100
$$

The color of Hom Khieo (HK) and Namwa (NW) starch was measured by colorimeter (Hunter Lab, Reston, VA, USA). The color was determined by the international color scale (International Commission on Illumination) which is in terms of CIELAB [67]. 


\subsection{Amylose Content}

Total amylose content was determined by using the colorimetric method described by Kaufman et al. [68]. The starch samples or standards $(5 \mathrm{mg})$ were weighed into a microcentrifuge tube. $1 \mathrm{~mL}$ of $90 \%$ DMSO in distilled water was added into the samples and heated for $60 \mathrm{~min}$ at $95^{\circ} \mathrm{C}$, then shaken every $10 \mathrm{~min}$ with a vortex. The samples were cooled down for $5 \mathrm{~min}$, then $100 \mu \mathrm{L}$ of each sample was placed into a 96-well plate. Both amylose and amylopectin were used to prepare a standard curve by varying the ratio (Table 4), and placed into the 96-well plate. Then, $100 \mu \mathrm{L}$ of $90 \%$ DMSO in distilled water with $3.04 \mathrm{~g} / \mathrm{L}$ of iodine was added into each well, and the plate was shaken for $2 \mathrm{~min}$. The $2 \mu \mathrm{L}$ of each well was transferred to the empty plate then $180 \mu \mathrm{L}$ of distilled water was added into each well and shaken for $2 \mathrm{~min}$ before being analyzed with absorbance at $620 \mathrm{~nm}$. The $100 \mu \mathrm{L}$ of DMSO with $3.04 \mathrm{~g} / \mathrm{L}$ and $100 \mu \mathrm{L}$ of $90 \%$ DMSO was used for the control blank. The amylose content was calculated as the following equation:

$$
\text { Amylose content }=\frac{\text { Absorbance at } 620 \mathrm{~nm}-\mathrm{y}-\text { intercept of regression }}{\text { Slope of regression }}
$$

Table 4. Standard curve preparation.

\begin{tabular}{ccc}
\hline Amylose Content (\%) & $\begin{array}{c}\text { Amount of } \mathbf{5} \mathbf{~ m g} / \mathbf{m L} \\
\text { Amylose Solution }(\boldsymbol{\mu L})\end{array}$ & $\begin{array}{c}\text { Amount of } \mathbf{5} \mathbf{~ m g} / \mathbf{m L} \\
\text { Amylopectin Solution }(\boldsymbol{\mu L})\end{array}$ \\
\hline 0 & 0 & 100 \\
5 & 5 & 95 \\
10 & 10 & 90 \\
15 & 15 & 85 \\
20 & 20 & 80 \\
25 & 25 & 75 \\
30 & 30 & 70 \\
50 & 50 & 50 \\
75 & 75 & 25 \\
100 & 100 & 0 \\
\hline
\end{tabular}

\subsection{Moisture Content}

The moisture content of the starch samples was determined by using a moisture analyzer (Ohaus, Parsippany, NJ, USA). One gram of each starch sample was placed into the moisture analyzer in condition of $100{ }^{\circ} \mathrm{C}$ for $1 \mathrm{~min}$ then the percentage of moisture content was recorded.

\subsection{Morphology}

The morphologies of HK and NW banana starches were determined by using a scanning electron microscopy (SEM) with SEI detector. The starch samples were placed on double-side adhesive carbon tape and coated with a gold layer. The starch sample granules were measured at $1000 \times$ magnification. The sizes of HK and NW starch granules were determined by using TESCAN Essence software (Zeiss, Jena, Germany).

\subsection{FT-IR Spectroscopy}

The FT-IR spectra of sample starches were recorded by spectrophotometer (PerkinElmer, Waltham, MA, USA) using the potassium bromide $(\mathrm{KBr})$ pellets method. The finely ground samples were mixed with dry $\mathrm{KBr}$ then pressed under high pressure to form $7 \mathrm{~mm}$ pellets then the sample was measured in the range of $4000-400 \mathrm{~cm}^{-1}$ with a resolution of $4 \mathrm{~cm}^{-1}$ and 16 scans, at room temperature [69].

\subsection{X-Ray Diffractometer (XRD)}

The crystallinity was measured by using an X-ray diffractometer (Malvern Panalytical, Malvern, UK) with a slightly modified version of the method used by Cheetham and 
Tao [34]. The HK and NW samples were packed tightly in aluminum cells then the intensities of samples were measured using the $\mathrm{X}$-ray diffractometer with $\mathrm{Cu} \mathrm{K} \alpha$ radiation $(\lambda=1.542)$, in the $3-40^{\circ} 2 \theta$ range with a $0.01^{\circ}$ step size and a measuring time of $10.0 \mathrm{~s}$ per point. The measurements were made at ambient temperature. The percentage crystallinity was calculated from the following equation [70].

$$
\text { Crystallinity }(\%)=\frac{\mathrm{Ac}}{\mathrm{Ac}+\mathrm{Aa}} \times 100
$$

where $\mathrm{Ac}=$ crystalline area and $\mathrm{Aa}=$ amorphous area.

\subsection{Differential Scanning Calorimetry (DSC)}

The thermal properties of the samples were analyzed by using differential scanning calorimetry with slightly modified version of the method used by Carmona-Garcia et al. [5]. Seven mg of each starch sample was weighed into an aluminum pan $(40 \mu \mathrm{L})$ then $20 \mu \mathrm{L}$ of distilled water was added and sealed tightly. The suspensions were allowed to stand at room temperature for $1 \mathrm{~h}$ before analysis. The samples were subjected to the DSC at a range of temperatures from 40 to $90^{\circ} \mathrm{C}$ and a heating rate of $10^{\circ} \mathrm{C} / \mathrm{min}$ under $\mathrm{N} 2$ atmosphere. The empty aluminum pan was used as a reference.

\subsection{Gelation}

Gelation of starch samples was determined by a slight modification of the method used by Lawal and Adebowals [71]. Starch samples were prepared at 0.5, 1, 2, 4, 6, 8, 10, 12 , and $14 \% w / v$ in test tubes with distilled water. The suspensions were mixed with a vortex until homogenous. The test tubes were heated in a water bath at $55,65,75$, and $80{ }^{\circ} \mathrm{C}$ for $30 \mathrm{~min}$ and cooled down with cold running tap water then cooled at $4{ }^{\circ} \mathrm{C}$ for $2 \mathrm{~h}$. The least gelation concentration was determined by the concentration when the test tube was inverted, and the sample did not slip or fall-down.

\subsection{Water and Oil Absorption Capacities}

A slightly modified version of the method used by Agnes et al. [47] was used to determine the water and oil absorption capacity. Ten $\mathrm{mL}$ of water or soybean oil was added to $1 \mathrm{~g}$ of each starch sample. The suspension was allowed to stand at room temperature for $30 \mathrm{~min}$ then centrifuged at $3500 \mathrm{rpm}$ for $30 \mathrm{~min}$. The supernatant was measured using a $10 \mathrm{~mL}$ cylinder. The difference between the initial water or oil used and the volume of the supernatant obtained after centrifuging was used to calculate the water or oil absorbed by the starch sample. The result was expressed as $\mathrm{g} / \mathrm{mL}$ of water or oil absorbed.

\subsection{Swelling Power and Solubility}

Swelling and solubility of the starch samples were determined by a slight modification of the method used by Carmona-Garcia et al. [5]. 1\% w/v of starch solution was prepared with distilled water in centrifuge tubes and water loss was prevented by covering the tubes with plastic caps. The tubes were then heated at $60,70,80$, and $90{ }^{\circ} \mathrm{C}$ for 30 min with shaking every $5 \mathrm{~min}$. After heating, the samples were centrifuged at $8000 \mathrm{rpm}$ for $5 \mathrm{~min}$. The supernatant was decanted, then both of supernatant and precipitate were dried at $100{ }^{\circ} \mathrm{C}$ overnight. The swelling power and solubility of the samples were determined by the following equation.

$$
\begin{gathered}
\text { Swelling power }=\frac{\text { Weight of swollen granules }}{\text { Weight of precipitate after dry }} \\
\text { Solubility }=\left(\frac{\text { Weight of solids in supernatant }}{\text { Weight of dry both of precipitate and supernatant }}\right) \times 100
\end{gathered}
$$




\subsection{Flowability}

\subsubsection{Bulk and Tapped Densities}

Measurement of the bulk, and tapped densities followed the method of Olayemi et al. [72]. Fifty grams $(\mathrm{Wp})$ of the starch samples were gently poured through a glass funnel into a $100 \mathrm{~mL}$ cylinder. The volume occupied by the sample was taken as $\mathrm{Vp}$. The powders were tapped on a wooden surface at height of 7 inches until no further change in volume was observed (VpT).

$$
\begin{aligned}
\mathrm{Bd} & =\frac{\mathrm{Vp}}{\mathrm{Wp}} \\
\mathrm{Td} & =\frac{\mathrm{VpT}}{\mathrm{Wp}}
\end{aligned}
$$

where $\mathrm{Bd}=$ Bulk density and $\mathrm{Td}=$ Tapped density.

\subsubsection{Compressibility Index and Hausner Ratio}

The bulk and tapped densities were used to calculate the compressibility index and the Hausner ratio to provide a measure of the flow properties [72,73].

$$
\begin{gathered}
\text { Hausnerratio }(\mathrm{HR})=\frac{\mathrm{Bd}}{\mathrm{Td}} \\
\text { Compressibility index }(\mathrm{CI})=\frac{(\mathrm{Bd}-\mathrm{Td})}{\mathrm{Bd}} \times 100
\end{gathered}
$$

\subsection{Preparation of Cosmetic Formulations}

Two powder formulations (body powder and compact powder) were prepared by varying the concentration of $\mathrm{HK}$ and NW starches to find the highest concentration suitable for the formulations. Body powder was composed of 5 to $20 \%$ HK or NW banana starch, talcum, magnesium carbonate, kaolin, zinc stearate, and zinc oxide. $1 \%$ of phenoxyethanol as a preservative was added to formula. Compact powder was composed of 5 to $20 \% \mathrm{HK}$ or NW, talcum, kaolin, zinc stearate, zinc oxide, titanium dioxide coated mica, magnesium stearate, and magnesium carbonate. Titanium dioxide, red iron oxide, yellow iron oxide, and black iron oxide as a colorant, $0.5 \%$ of capric/caprylic triglyceride, $1 \%$ of mineral oil, and $1 \%$ of isopropyl myristate as binding agents, and $1 \%$ of phenoxyethanol as a preservative were added to formula.

\section{Conclusions}

The banana starch of Hom Khieo (HK) and Namwa (NW) cultivars were successfully extracted with $1 \%$ sodium sulfite with a high yield based on unripe peeled banana fruit. The starches showed light-yellow color with a fine powder. The morphology of both starches was oval shape with elongated forms for large granules and round shapes for small granules. The amylose content of HK and NW were $24.99 \%$ and $26.23 \%$, respectively. Each starch showed the B-type crystalline structure and the gelatinization temperature was around $77^{\circ} \mathrm{C}$. The banana starches showed very poor flow character and provide smoothness when applied on skin. The HK and NW banana starch were used in powder formulations to provide a smooth feel and good spreading properties. The starch has the potential to be used as a substitute for talcum in powder base preparation with no effect on sensorial properties at $15 \% w / w$ maximum.

Author Contributions: Conceptualization, A.J. and S.R.; Methodology, A.J. and N.T.; Validation, A.J. and N.T.; Formal Analysis, A.J. and N.T.; Investigation, N.T.; Resources, N.T. and S.R.; Data Curation, A.J. and N.T.; Writing-Original Draft Preparation, A.J. and N.T.; Writing-Review \& Editing, A.J. and S.R.; Visualization, N.T.; Supervision, A.J.; Project Administration, A.J.; Funding Acquisition, A.J. and S.R. All authors have read and agreed to the published version of the manuscript.

Funding: This work was supported by Mae Fah Luang University, grant number 622A04055. 
Institutional Review Board Statement: Not applicable.

Informed Consent Statement: Not applicable.

Data Availability Statement: All the data are available in the manuscript.

Conflicts of Interest: The authors declare no conflict of interest.

Sample Availability: Samples of the compounds HK and NW starch are available from the authors.

\section{References}

1. Torre-Gutiérrez, L.D.; Chel-Guerrero, L.A.; Betancur-Ancona, D. Functional properties of square banana (Musa balbisiana) starch. J. Food Chem. 2008, 106, 1138-1144. [CrossRef]

2. Moorthy, S.N. Tropical source of starch. In Starch in Food: Structure, Function, and Application, 1st ed.; Eliasson, A.C., Ed.; Woodhead Publishing Limited: Cambridge, UK; CRC Press LLC: New York, NY, USA, 2004; pp. 321-359. [CrossRef]

3. Fahrasmane, L.; Parfait, B.; Aurore, G. Bananas, a source of compounds with health properties. Acta Hortic. 2014, 1040, 75-82. [CrossRef]

4. Crane, J.H.; Balerdi, C.F. The banana in Florida; Institute of Food and Agricultural Sciences, University of Florida: Gainesville, FL, USA, 1998; Volume 10, pp. 1-8.

5. Carmona-Garcia, R.; Sanchez-Rivera, M.M.; Méndez-Montealvo, G.; Garza-Montoya, B.; Bello-Pérez, L.A. Effect of the crosslinked reagent type on some morphological, physicochemical and functional characteristics of banana starch (Musa paradisiaca). J. Carb. Pol. 2009, 76, 117-122. [CrossRef]

6. Cordenunsi, B.R.; Lajolo, F.M. Starch breakdown during banana ripening: Sucrose synthase and sucrose phosphate synthase. J. Agric. Food Chem. 1995, 43, 347-351. [CrossRef]

7. Valmayor, R.V. Banana Cultivar Names and Synonyms in Southeast Asia, 1st ed.; International Network for the Improvement of Banana and Plantain-Asia and the Pacific Office: Los Baños, Laguna, Philippines, 2000; pp. 8-12.

8. Zhang, P.; Whistler, R.L.; Bemiller, J.N.; Hamaker, B.R. Banana starch: Production, physicochemical properties, and digestibilityA review. J. Carb. Pol. 2005, 59, 443-458. [CrossRef]

9. Mazza, G.; Biliaderis, C.G.; Przybylski, R.; Oomah, B.D. Compositional and morphological characteristics of cow cockle (Saponaria vaccaria) seed, a potential alternative crop. J. Agric. Food Chem. 1992, 40, 1520-1523. [CrossRef]

10. Shevkani, K.; Singh, N.; Bajaj, R.; Kaur, A. Wheat starch production, structure, functionality and applications-A review. Int. J. Food Sci. Technol. 2016, 52, 38-58. [CrossRef]

11. Cornejo-Ramírez, Y.I.; Martínez-Cruz, O.; Toro-Sánchez, C.L.; Wong-Corral, F.J.; Borboa-Flores, J.; Cinco-Moroyoqui, F.J. The structural characteristics of starches and their functional properties. CyTA J. Food 2018, 16, 1003-1017. [CrossRef]

12. Lehmann, A.; Volkert, B.; Fischer, S.; Schrader, A.; Nerenz, H. Starch based thickening agents for personal care and surfactant systems. Colloids and Surfaces A: Physicochem. Eng. Aspects. 2008, 331, 150-154. [CrossRef]

13. Yazid, N.S.M.; Abdullah, N.; Muhammad, N.; Matias-Peralta, H.M. Application of starch and starch-based products in food industry. J. Sci. Technol. 2018, 10, 144-174. [CrossRef]

14. Rincón, A.M.; Pérez, R.M.N.; Reyes, A.; Romero, A.; Orfila, L.; Padilla, F.C. 'Guapo' (Myrosma cannifolia) starch: A natural product with potential use in cosmetic formulations. Int. J. Cosmet. Sci. 2005, 27, 107-114. [CrossRef]

15. Boonme, P.; Aporn, M.; Khwankaew, S.; Pichayakorn, W.; Prapruti, P.; Boromthanarat, S. Feasibility study of sago starch for perfumed and cooling body powders. Cosm. Toil. 2009, 124, 30-37.

16. Thanyapanich, N.; Jimtaisong, A.; Rawdkuen, S. Extraction and Characterization of Banana (Musa acuminata) Starch for Cosmetic Application. In Proceedings of the Cosmetic \& Beauty International Conference 2019, Chiang Rai, Thailand, 7-9 October 2019.

17. Bello-Pérez, L.A.; Agama-Acevedo, E.; Sánchez-Hernández, L.; Paredes-López, O. Isolation and partial characterization of banana starches. J. Agric. Food Chem. 1999, 47, 854-857. [CrossRef]

18. Chávez-Salazar, A.; Bello-Pérez, L.A.; Agama-Acevedo, E.; Castellanos-Galeano, F.J.; Álvarez-Barreto, C.I.; Pacheco-Vargas, G. Isolation and partial characterization of starch from banana cultivars grown in Colombia. Int. J. Biol. Macromol. 2017, 98, 240-246. [CrossRef]

19. Falade, K.O.; Oyeyinka, S.A. Color, chemical and functional properties of plantain cultivars and cooking banana flour as affected by drying method and maturity. J. Food Process. Preserv. 2014, 39, 816-828. [CrossRef]

20. Abdullah, A.H.D.; Chalimah, S.; Primadona, I.; Hanantyo, M.H.G. Physical and Chemical Properties of Corn, Cassava, and Potato Starches. In Proceedings of the 2nd International Symposium on Green Technology, Jakarta, Indonesia, 26-27 September 2018.

21. Alcázar-Alay, S.C.; Meireles, M.A. Physicochemical properties, modifications and applications of starches from different botanical sources. Food Sci. Technol. 2015, 35, 215-236. [CrossRef]

22. Barros Mesquita, C.D.; Leonel, M.; Franco, C.M.; Leonel, S.; Garcia, E.L.; Santos, T.P. Characterization of banana starches obtained from cultivars grown in Brazil. Int. J. Biol. Macromol. 2016, 89, 632-639. [CrossRef] [PubMed]

23. Utrilla-Coello, R.G.; Rodríguez-Huezo, M.E.; Carrillo-Navas, H.; Hernámdez-Jaimes, C.; Vernon-Carter, E.J.; Alvarez-Ramirez, J. In vitro digestibility, physicochemical, thermal and rheological properties of banana starches. J. Carb. Pol. 2014, 101, 154-162. [CrossRef] 
24. Crouter, A.; Briens, L. The effect of moisture on the flowability of pharmaceutical excipients. AAPS PharmSciTech 2013, 15, 65-74. [CrossRef] [PubMed]

25. Juarez-Enriquez, E.; Olivas, G.I.; Zamudio-Flores, P.B.; Ortega-Rivas, E.; Perez-Vega, S.; Sepulveda, D.R. Effect of water content on the flowability of hygroscopic powders. J. Food Eng. 2017, 205, 12-17. [CrossRef]

26. Bello-Pérez, L.A.; de Francisco, A.; Agama-Acevedo, E.; Gutierrez-Meraz, F.; García-Suarez, F.J.L. Morphological and molecular studies of banana starch. Food Sci. Technol. Int. 2005, 11, 367-372. [CrossRef]

27. Izidoro, D.R.; Junior, B.D.; Haminiuk, W.I.; Sierakoeski, M.R.; Freitas, R.J.S.; Scheer, A.P. Granules morphology and rheological behavior of green banana (Musa cavendishii) and corn (Zea mays) starch gels. Ciênc. Agrotec. 2007, 31, 1443-1448. [CrossRef]

28. Kayisu, K.; Hood, L.F.; Vansoest, P.J. Characterization of starch and fiber of banana fruit. J. Food Sci. 1981, 46, 1885-1890. [CrossRef]

29. Lii, C.Y.; Chang, S.M.; Young, Y.L. Investigation of the physical and chemical properties of banana starches. J. Food Sci. 1982, 47, 1493-1497. [CrossRef]

30. Reddy, C.K.; Haripriya, S.; Vidya, P.V. Morphology, physico-chemical and functional characteristics of starches from different banana cultivars. J. Food Sci. Technol. 2015, 52, 7289-7296. [CrossRef]

31. Singh, N.; Singh, J.; Kaur, L.; Sodhi, N.S.; Gill, B.S. Morphological, thermal and rheological properties of starches from different botanical sources. J. Food Chem. 2003, 81, 219-231. [CrossRef]

32. Oates, C.G. Towards an understanding of starch granule structure and hydrolysis. Trends Food Sci. Technol. 1997, 8, 375-382. [CrossRef]

33. Yoo, S.H.; Jane, J.L. Structural and physical characteristics of waxy and other wheat starches. J. Carb. Pol. 2002, 49, 297-305. [CrossRef]

34. Cheetham, N.W.H.; Tao, L. Variation in crystalline type with amylose content in maize starch granules: An X-ray powder diffraction study. J. Carb. Pol. 1998, 36, 277-284. [CrossRef]

35. Jiranuntakul, W.; Puttanlek, C.; Rungsardthong, V.; Puncha-Arnon, S.; Uttapap, D. Microstructural and physicochemical properties of heat-moisture treated waxy and normal starches. J. Food Eng. 2011, 104, 246-258. [CrossRef]

36. Zhang, Z.; Tian, X.; Wang, P.; Jiang, H.; Li, W. Compositional, morphological, and physicochemical properties of starches from red adzuki bean, chickpea, faba bean, and baiyue bean grown in China. Food Sci. Nutr. 2019, 7, 2485-2494. [CrossRef] [PubMed]

37. Sarko, A.; Wu, H.C.H. The crystal structures of A-, B- and C-polymorphs of amylose and starch. Starke 1978, 30, 73-78. [CrossRef]

38. Ao, Z.; Jane, J.L. Characterization and modeling of the A- and B-granule starches of wheat, triticale, and barley. J. Carb. Pol. 2007, 67, 46-55. [CrossRef]

39. Brites, C.M.; Santos, C.A.L.; Bagulho, A.S.; Beirão-da-Costa, M.L. Effect of wheat puroindoline alleles on functional properties of starch. Eur. Food Res. Technol. 2008, 226, 1205-1212. [CrossRef]

40. Stevnebø, A.; Sahlström, S.; Svihus, B. Starch structure and degree of starch hydrolysis of small and large starch granules from barley varieties with varying amylose content. Anim. Feed Sci. Technol. 2006, 130, 23-38. [CrossRef]

41. Shi, M.; Wang, K.; Yu, S.; Gilbert, R.G.; Gao, Q. Structural characterizations and in vitro digestibility of acid-treated wrinkled and smooth pea starch (Pisum sativum L.). Starke 2016, 68, 762-770. [CrossRef]

42. Geera, B.P.; Nelson, J.E.; Souza, E.; Huber, K.C. Composition and properties of A- and B-type starch granules of wild-type, partial waxy, and waxy soft wheat. Cereal Chem. 2006, 83, 551-557. [CrossRef]

43. Sasaki, T.; Yasui, T.; Matsuki, J. Effect of amylose content on gelatinization, retrogradation, and pasting properties of starches from waxy and nonwaxy wheat and their F1 seeds. Cereal Chem. 2000, 77, 58-63. [CrossRef]

44. Mar, N.N.; Umemoto, T.; Abdulah, S.N.A.; Maziah, M. Chain length distribution of amylopectin and physicochemical properties of starch in Myanmar rice cultivars. Int. J. Food Prop. 2015, 18, 1719-1730. [CrossRef]

45. Jane, J.; Chen, Y.Y.; Lee, L.F.; Mcpherson, A.E.; Wong, K.S.; Radosavljevic, M.; Kasemsuwan, T. Effects of amylopectin branch chain length and amylose content on the gelatinization and pasting properties of starch. Cereal Chem. 1999, 76, 629-637. [CrossRef]

46. Ritika, B.Y.; Khatkar, B.S.; Yadav, B.S. Physicochemical, morphological, thermal and pasting properties of starches isolated from rice cultivars grown in India. Int. J. Food Prop. 2010, 13, 1339-1354. [CrossRef]

47. Agnes, A.C.; Felix, E.C.; Ugochukwu, N.T. Morphology, rheology and functional properties of starch from cassava, sweet potato and cocoyam. Asian J. Conserv. Biol. 2017, 3, 1-13. [CrossRef]

48. Akinwale, T.E.; Niniola, D.M.; Abass, A.B.; Shittu, T.A.; Adebowale, A.A.; Awoyale, W.; Awonorin, S.O.; Adewuyi, S.; Eromosele, C.O. Screening of some cassava starches for their potential applications in custard and salad cream productions. J. Food Meas. Charact. 2017, 11, 299-309. [CrossRef]

49. Chisenga, S.M.; Workneh, T.S.; Bultosa, G.; Laing, M. Characterization of physicochemical properties of starches from improved cassava varieties grown in Zambia. AIMS Agric. Food 2019, 4, 939-966. [CrossRef]

50. Demiate, I.M.; Kotovicz, V. Cassava starch in the Brazilian food industry. Ciênc. Tecnol. Aliment. 2011, 31, 388-397. [CrossRef]

51. Nuwamanya, E.; Baguma, Y.; Emmambux, N.; Taylor, J.; Patrick, R. Physicochemical and functional characteristics of cassava starch in Ugandan varieties and their progenies. J. Plant Breed. Crop Sci. 2010, 2, 1-11.

52. Rodríguez-Torres, D.; Murillo-Arango, W.; Vaquiro-Herrera, H.A.; Solanilla-Duque, J.F. Thermal and physicochemical properties of starches from three Colombian rice varieties. Agron. Colomb. 2017, 35, 116-124. [CrossRef]

53. Tang, H.; Mitsunaga, T.; Kawamura, Y. Relationship between functionality and structure in barley starches. J. Carb. Pol. 2004, 57, 145-152. [CrossRef] 
54. Song, Y.; Jane, J. Characterization of barley starches of waxy, normal, and high amylose varieties. J. Carb. Pol. 2000, 41, 365-377. [CrossRef]

55. Nor Nadiha, M.Z.; Fazilah, A.; Bhat, R.; Karim, A.A. Comparative susceptibilities of sago, potato and corn starches to alkali treatment. J. Food Chem. 2010, 121, 1053-1059. [CrossRef]

56. Mtunguja, M.K.; Thitisaksakul, M.; Muzanila, Y.C.; Wansuksri, R.; Piyachomkwan, K.; Laswai, H.S.; Chen, G.; Shoemaker, C.F.; Sinha, N.; Beckles, D.M. Assessing variation in physicochemical, structural, and functional properties of root starches from novel Tanzanian cassava (Manihot esculenta Crantz.) landraces. Starke 2016, 68, 514-527. [CrossRef]

57. Sánchez, T.; Dufour, D.; Moreno, I.X.; Ceballos, H. Comparison of pasting and gel stabilities of waxy and normal starches from potato, maize, and rice with those of a novel waxy cassava starch under thermal, chemical, and mechanical stress. J. Agric. Food Chem. 2010, 58, 5093-5099. [CrossRef] [PubMed]

58. Craik, D.J. The flow properties of starch powders and mixtures. J. Pharm. Pharmacol. 1958, 10, 73-79. [CrossRef]

59. Ortega-Rivas, E. Unit Operations of Particulate Solids: Theory and Practice, 1st ed.; Taylor \& Francis Group: Abingdon-on-Thames, UK; CRC Press: Boca Raton, FL, USA, 2012.

60. Ostrowska-Ligeza, E.; Lenart, A. Influence of water activity on the compressibility and mechanical properties of cocoa products. LWT Food Sci. Technol. 2015, 60, 1054-1060. [CrossRef]

61. Shenoy, P.; Xanthakis, E.; Innings, F.; Jonsson, C.; Fitzpatrick, J.; Ahrné, L. Dry mixing of food powders: Effect of water content and composition on mixture quality of binary mixtures. J. Food Eng. 2015, 149, 229-236. [CrossRef]

62. Amberg, N.; Fogarassy, C. Green consumer behavior in the cosmetics market. Resources 2019, 8, 137. [CrossRef]

63. Gubitosa, J.; Rizzi, V.; Fini, P.; Pinalysa, C. Hair care cosmetics: From traditional shampoo to solid clay and herbal shampoo, a review. Cosmetics 2019, 6, 13. [CrossRef]

64. Moon, M.C.; Park, J.D.; Choi, B.S.; Park, S.Y.; Kim, D.W. Risk Assessment of Baby Powder Exposure through Inhalation. Toxicol. Res. 2011, 27, 137-141. [CrossRef]

65. O'Brien, K.M.; Tworoger, S.S.; Harris, H.R.; Anderson, G.L.; Weinberg, C.R.; Trabert, B.; Kaunitz, A.M.; D'Aloisio, A.A.; Sandler, D.P.; Wentzensen, N. Association of powder use in the genital area with risk of ovarian cancer. JAMA 2020, 323, 49-59. [CrossRef] [PubMed]

66. Pasapane, J.; Solarek, D.; Wilson, N. Specialty starches for personal care. Cosm. Toil. 1999, 114, 79-82.

67. Melo Neto, B.A.; Bonomo, R.C.F.; Franco, M.; de Almeida, P.F.; Pontes, K.V. Starch extraction from the peach palm (Bactris gasepaes Kunth.) fruit: A model approach for yield increase. Eng. Agricola. 2017, 37, 148-159. [CrossRef]

68. Kaufman, R.C.; Wilson, J.D.; Bean, S.R.; Herald, T.J.; Shi, Y.C. Development of a 96-well plate iodine binding assay for amylose content determination. J. Carb. Pol. 2015, 115, 444-447. [CrossRef]

69. Pozo, C.; Rodríguez-Llamazares, S.; Bouza, R.; Barral, L.; Castaño, J.; Müller, N.; Restrepo, I. Study of the structural order of native starch granules using combined FTIR and XRD analysis. J. Polym. Res. 2018, 25. [CrossRef]

70. Ferreira, C.D.; Ziegler, V.; Halal, S.L.M.; Vanier, N.L.; Zavareze, E.R.; Oliveira, M. Characteristics of starch isolated from black beans (Phaseolus vulgaris L.) stored for 12 months at different moisture content and temperatures. Starke. 2016, 69. [CrossRef]

71. Lawal, O.S.; Adebowale, K.O. Physicochemical characteristics and thermal properties of chemically modified jack bean (Canavalia ensiformis) starch. J. Carb. Pol. 2005, 60, 331-341. [CrossRef]

72. Olayemi, O.J.; Oyi, A.R.; Allagh, T.S. Comparative evaluation of maize, rice and wheat starch powders as pharmaceutical excipients. Niger. J. Pharm. Sci. 2008, 7, 131-138.

73. Shah, R.B.; Tawakkul, M.A.; Khan, A. Comparative evaluation of flow for pharmaceutical powders and granules. AAPS PharmSciTech 2008, 9, 250-258. [CrossRef] [PubMed] 